\title{
A Review of Building Energy Efficiency Technology
}

\author{
Ronglan Zhang \\ School of Civil Engineering, Yancheng Institute of Technology, Yancheng, China \\ Email: z71rl@126.com
}

Received 26 August 2015; accepted 21 November 2015; published 24 November 2015

Copyright (C) 2015 by author and Scientific Research Publishing Inc.

This work is licensed under the Creative Commons Attribution International License (CC BY).

http://creativecommons.org/licenses/by/4.0/

(c) (i) Open Access

\begin{abstract}
In China, there's high energy consumption in buildings with less attention to building energy efficiency. All of these facts prove that there are great potentialities in energy conservation. On account of this, this paper introduces multiple building energy-saving technologies at home and abroad, including the technologies for innovative wall materials, exterior wall external insulation, heat insulation of window, utilization of solar energy, heat storage and recovery as well as the illumination energy saving technology. On the basis of new buildings, this paper gives five suggestions on building energy efficiency. Meanwhile it raises five suggestions on energy conservation based on the existing building, for which it presents purposely the technologies and measures about energy saving transformation from four aspects.
\end{abstract}

\section{Keywords}

Importance, Building Energy Efficiency, Measures

\section{Importance and Feasibility of Building Energy Efficiency}

\subsection{Over 90\% Buildings in China of High Energy Consumption}

The status of energy consumption is not optimistic for buildings in China. It is shown by statistics that among the existing buildings in the urban and rural areas in China covering a total area of over $43 \mathrm{billion} / \mathrm{m}^{2}$, only about $5 \%$ achieves the energy-saving standard; even among the new buildings, the buildings of high energy consumption still account for over $90 \%$.

The largest energy consumption adopted in the buildings in China is the heating and cooling, about three times as much as those developed countries with the similar climate conditions.

It is also indicated that the total building energy consumption is rising year by year in China to approximately $30 \%$ in recent years from $10 \%$ at the end of the 1970s in the total energy consumption [1]. It is pointed out by experts that the gross area of approximately 2 billion $/ \mathrm{m}^{2}$ is occupied for buildings now every year, meaning that 
the building energy consumption will reach 1 billion tons of standard coal by 2020 if this trend continues.

\subsection{From the Perspective of Quality and Benefits of Town Development}

At present, the construction of residential and public buildings has not fundamentally gotten rid of the extensive mode of growth, and the problems of high input, high consumption, high pollution and low output have not been solved well, thus causing huge waste of resources and environmental pollution, and highlighting the conservations in energy, water, land and materials respectively (hereinafter referred to as the "four conservations").

With respect to energy-saving, 95\% of the existing buildings fail to reach the energy conservation standard, and no more than $20 \%$ of new buildings meet the energy conservation standard, indicating that the attention paid to building energy efficiency is not enough. Some cities and towns even blindly pursue the night lighting, which wastes a lot of resources.

\subsection{From the Perspective of Great Potential of Building Energy Efficiency}

Facing the serious problems, we shall notice the tremendous potential of energy efficiency in the residential and public buildings in China. It is predicted that by 2020, if the town buildings meet the energy conservation standard, 335 million tons of standard coal will be saved each year, and the 80 million KWH will be reduced for the peak load of air conditioning, equivalent to the aggregate installed capacity of new power from 1998 to 2003, equivalent to 4.5 times the output of the Three Gorges Dam, and equivalent to RMB 1000 billion saved every year for the investment in electric power construction.

Attention of relevant authorities has been attracted by the building energy efficiency. China began to try out the first design standard on building energy efficiency in 1986, and incorporated the design standard on building energy efficiency in the northern area of China in the mandatory standard in 1999. In recent years, the General Office of the State Council and the Ministry of Construction have successively issued such documents as the Notice on Further Boosting the Innovation in Wall Materials and the Promotion of Energy-saving Buildings and the Guidelines on the Development of Energy-saving and Ground-saving Residential and Public Buildings to enhance the building energy efficiency. The concrete implementation measures have been introduced in various regions to reduce the building energy consumption.

Save water and materials, and then the energy will be saved. In fact, the consumption of materials and water is the consumption of energy. Both clean water and materials come from energy. About RMB 1000 billion is invested in real estate (commercial housing) in China every year, and 500 billion in urban infrastructures excluding rural buildings, all consuming large numbers of materials. Therefore, a lot of energy will be saved if it is possible to save water and materials.

\section{Instances of Building Energy Efficiency at Home and Abroad}

\subsection{Instances of Building Energy Efficiency at Home}

It is found out by NPC Enforcement Inspection Group of Energy Conservation Law that the building energy efficiency has achieved good effects in Zhejiang and Jilin. Both solar heating water and new building materials are widely used in the 60 demonstration projects in Zhejiang Province identified in 2005. In Jilin Province, it is focused on the innovation in wall materials to form a good situation of "ensure building energy efficiency with wall material reformation, and enhance wall material reformation with building energy efficiency".

It is introduced that compared to the ordinary buildings, the demonstrated energy-efficient buildings in Zhejiang Province has a indoor temperature difference of $2^{\circ} \mathrm{C}-5^{\circ} \mathrm{C}$, the air conditioning usage time greatly reduced, and energy expenditure reduced by a third even half; in Jilin Province, $90 \%$ of the new buildings satisfy the energy saving design standard, with the winter indoor temperature generally above $18^{\circ} \mathrm{C}$. It is measured that after the complete implementation of energy saving standard for all new building in Zhejiang Province, 3.5 billion KWH power will be saved each year, accounting for $1.8 \%$ of the total electricity demand in the province, equivalent to 1.22 million tons of standard coal; in Jilin Province, the heating energy consumption of unit building area is reduced by $3 \mathrm{~kg}$ of standard coal from last year.

\subsection{Instances of Building Energy Efficiency Abroad}

Concrete energy-saving technologies in Europe: 
Exterior wall insulation technology: the expanded polystyrene doped with graphite shall be adopted for a better thermal insulation performance, with the thermal conductivity $20 \%$ lower than the ordinary polystyrene; with the polystyrene insulation thickness of some exterior walls up to $20 \mathrm{~cm}$, and the roof up to $29 \mathrm{~cm}$, the thermal insulation effect is extremely good; the industrialized manner is used for the reformation of exterior walls of existing buildings to make the external thermal insulation consistent with the internal decoration.

Window insulation technology: a variety of blinds, shutters and windows are used for shading, heat preservation and heat insulation; the three layers of hollow glass window are used, of low emissivity and filled with inert gases; thermal insulation materials are used outside the window to insulate the heat.

Utilization of solar energy [2]: the adjustable blinds shall be adopted to make full use of the sunlight and to avoid the glare; the photovoltaic cell may be used to power the buildings, the excess power into the grid, the insufficient power supplied by the grid; the ventilated solar house with automatic shutter may both use the solar for heating and avoid the overheating.

Heat storage and recovery technology: huge concrete floor is installed as the heat retainer, which may be used for cooling and heating if filled with ground water flux, and recycle the heat of indoor air by exchanging the hot air out of with the indoor air into the house, with the heat recovery rate up to 85\%; mix the plasterer with paraffin particles which may correspondingly absorb or release heat under the changes in external temperature, thus making the room temperature stable, warm in winter and cool in summer; no air conditioning is required in summer under the air conditions in Western Europe.

Waste recycling technology: build the wall with dismantled bricks; use the old wood brick as the floor block; collect the roof rainwater for water washing, toilet flushing and gardening.

Energy saving technology in lighting: adopt efficient lighting lamps and lanterns, and adjust the intensity of illumination as per the environmental brightness measured by the sensor.

Attaching great importance to energy saving, many European countries [3] have formulated various heat metering standards and regulations on centralized heating, and even set up multi-national heating metering alliance (E.V.V.E). Such management and technology measures have played an important role in promoting the further development of building energy efficiency, and are worth our using for reference and study.

\section{Measures to Realize Building Energy Efficiency}

The building energy efficiency shall be comprehensively promoted by the reform of urban heating system and the reform of heating refrigeration mode, focusing on energy-saving and cost-reducing of public buildings. All new buildings must strictly comply with the building energy efficiency standard, with the supervision of implementation strengthened. The energy efficiency policies and pilot demonstration of existing buildings shall be focused to accelerate the energy-saving reform of existing public buildings by governments. The application of new and renewable energy shall be promoted actively. Various functions of the cities shall be arranged reasonably; the urban residence and employment shall be laid rationally; the traffic load shall be reduced; and the energy consumption of urban traffic shall be lowered.

\subsection{Suggestions on the Energy Conservation in New Buildings}

Over 10 years for promoting the building energy efficiency, a complete set of standards has been formed, most related technologies have become mature, the promotion measures have been introduced successively, so it is basically equipped with the condition to comprehensively enhance the energy-saving and ground-saving in new buildings.

First of all, fully implement the energy-saving and ground-saving design standard nationwide, carry out the strictest inspection system, adopt the severest punishment measures, and execute the compulsory energy-saving and ground-saving standards or provisions from all links including design, construction drawing review, construction, supervision, testing and acceptance. Encourage the qualified project and region to take the lead in achieving the energy-saving standard of $65 \%$ or even $75 \%$; promote the implementation of household metering (or heat metering or household control, take the heat metering); enforce the standards of energy saving, water saving and material saving, encourage the new efficient technology, products and materials, actively apply the new renewable energy sources, pay attention to the design in structure durability, and extend the whole life cycle of housing and buildings. Actively organize the publicity and implementation in the industry, conduct the promotion activities nationwide, and bind the regulations, policies, standards, specifications, promotion measures, 
scientific and technological achievements and pilot demonstrations related to the development of energy-saving and ground-saving residential and public buildings for the guidance.

Secondly, establish and improve the planning system comprehensively promoting the conservations in energy, water and materials and the environmental protection, and incorporate the energy-saving and ground-saving residential and public buildings into the index framework system of urban and rural construction land. Straighten out as soon as possible the standards system of energy-saving and ground-saving residential and public buildings, and introduce the design review and completion acceptance measures implementing the mandatory energy-saving and ground-saving provisions.

Thirdly, further study and improve the industrial policies, technological policies and economic policies advancing the "four conservations" in new buildings; analyze the economic and social benefits by advancing the "four conservations" in new buildings; study and formulate improved measures for heating charge in the new energy-saving and ground-saving residential and public buildings; study and formulate incentives on comprehensively advancing the energy-saving and ground-saving residential and public buildings, and classify and refine the same to ensure the effective connection of operability with economic and technical policies. Coordinate, regulate and unify various internal incentives [4].

Fourthly, conduct special inspections and publicize the results.

Finally, complete as soon as possible a batch of scientific and technological researches having key impacts on the comprehensive promotion of energy-saving and ground-saving residential and public buildings, and incorporate the results into the standard specification for perfection.

\subsection{Suggestions on the Energy Conservation in Existing Buildings}

The promotion of "four conservations" in existing buildings is the key to building energy efficiency. The building energy efficiency may be realized by the reform in not only the heat insulation of residential or public buildings, but also the water-saving facilities. The following suggestions are put forward hereby:

First of all, make a comprehensive baseline survey to the existing town buildings, and analyze the implementation of energy-saving and ground-saving standards for new buildings in recent years, buildings after liberation, and buildings before liberation for the convenience of classified guidance, thus providing the basis for the further development of industrial policies, technological policies and economic policies with respect to the remodeling of energy-saving for existing buildings.

Secondly, the Ministry of Construction shall together with the relevant ministries and commissions under the State Council formulate and introduce guidelines on the implementation of energy saving measures in the existing town buildings, form a clear, reasonable and suitable economic policy guidelines for classified direction, give full play to the role of market mechanism, and appropriately combine the enthusiasms of the central finance department, the local finance department and the real estate units or habitants.

Thirdly, increase the energy-saving pilot demonstrations in the Three-North Regions (North, Northeast and Northwest China), transition region and South China while strengthening the full implementation of energysaving reform for existing public buildings; in addition, accelerate the promotion of the reform in urban heating systems [4].

Fourthly, propagandize the industrial policies, technological policies, economic policies, laws, regulations, standards, norms, and successful experience of demonstration cities with respect to the remodeling of energysaving for existing buildings.

Finally, comprehensively boost the energy conservation in existing town buildings nationwide.

\section{Energy Saving Technology for the Reconstruction of Existing Buildings [5]}

Energy saving reconstruction of existing buildings is involved with the external wall (including the nontransparent curtain wall and the non-heating stairway enclosure), the roof, the external doors and windows (including the transparent curtain wall, the entrance door and the unenclosed balcony door) as well as the floors exposed to the outside air and the partitions and floor slabs between and the heating space and the unheated space.

\subsection{Wall Reconstruction Technology}

Give priority to adopt the exterior insulation technology. However it's suitable to adopt the internal insulation 
technology when it becomes very hard to continue the construction or maintain the original appearance of the building through the exterior insulation in cold areas or the areas where it's hot in summer and frigid in winter. Take the following measures including light-color processing and the additional construction of a heat preservation and insulation layer on the walls in the region where it's hot in summer but warm in winter or with a moderateclimate. During the design of the externalthermalinsulation, make sure to combine it with water resistance and decoration so as to have a good sealing and waterproof design on the insulatinglayer.

Measures for wall external insulations include the application of the following external insulation systems, such as the EPS board, the XPS board, the rock wool board, the fabricatedcompound board with insulation and decoration and the curtain wall-like board etc., while the measures for the interior wall insulation include the application of the following interior insulation systems: the insulation mortar consisting of gelatinous powder and expanded polystyrene pellets, the thermalmortar and the strengthened gypsum-coated polystyrene plate etc.

\subsection{Door and Window Reconstruction Technology}

The design on the energy-saving reconstruction of windows must conform to the various properties in terms of security, soundinsulation, ventilation and lighting etc. In cold or severecoldarea, all of the doors must be heat insulated. Even if necessary, a foyer must be built after the door. Adopt heat insulation door when the door is located in a non-heating aisle. Also it's applicable to install another window outside (or within) the original single-glazed window at a distance of around $100 \mathrm{~mm}$ in the cold or severecoldarea. In the case that the original window is located on the innerside, take measures to improve its sealingproperty. During the replacement of a window, make sure to design a proper insulation and seal structure between the window frame and the wall to reduce the cracking, moisture condensation and air infiltration on the position. Meanwhile it's feasible to adopt movable external sunshade in the east-westdirection in a cold area or the area where it's hot in summer and cold in winter. However in the area where it's hot in summer but warm in winter, give priority to improve the window shading in addition to the adoption of the following measures such as replacement of glass, installation of external shading facilities and the application of heat-insulatingfilm etc.

\subsection{Roof Reconstruction Technology}

Regarding the energy saving reconstruction of roof, take the proper reconstructivemeasures according to the types of the roof. For example, adopt the inverted roof when the original roof shows reliable waterproof performance. However it's necessary to remove the original waterproof layer, reconstructing the insulating layer and the waterproof layer when there's leakage in the original waterproof layer. Under the circumstance that a flat roof is replaced by a sloping roof, it's a proper measure to construct an insulating layer with excellent durability and good fireproof performance on the flat roof of the original building. During the reconstruction of a sloping roof, make sure to lay light-weight thermal insulation materials over the original ceiling. But in the case that there's no ceiling available, it's applicable to construct additionally or thicken the insulating layer or construct a new ceiling, which is laid over with thermal insulation materials on the sloping roof. The ceiling must be fireproof with good durability and security. Take ventilating measures in the area where it's hot in summer and cold in winter or it's hot in summer but warm in winter to prevent the sweltering loft. But if the condition allows, it's an appropriate measure to adopt the planted roof.

\subsection{Reconstruction of the Other Parts}

If it's an unheated space under the ground floor of the building, construct additionally an insulatinglayer on the floor slab through the following measures such as bond, combination of bond \& nailing or through the hung ceiling to locate the insulatinglayer at the bottom of the floor slab. If fireprevention is required in the lower space, then both of the thermal insulation materials and the construction method must conform to the fire rating requirements.

Currently the measures for the reconstruction of existing curtain walls include: Take full advantage of the interlayer space to adopt effective insulation measures. Reduce the actual area ratio of window to wall. Replace the glass with low shading coefficient and install additionally the interior shading facilities in the area where it's hot in summer but warm in winter. In the cold or severe cold area and the area where it's hot in summer but cold in winter, it's applicable to install another window on the original one in the room. Regarding the nontransparent curtain wall, it's feasible to add an insulating layer based on the indoor layer. 


\section{Conclusion}

As a long-term systematic project, at present, the building energy conservation requires the improvement of the systems, the practical operability, and the general improvement of the national consciousness. Moreover, the prompt formulation of policy systems undoubtedly has an important practical significance in both guiding the energy conservation and motivating the industry enthusiasm.

\section{References}

[1] Zhou, X.F. (2006) Analysis of Energy-Saving Potential and Measures for Rural Residences. Energy Engineering in China, 62.

[2] Ma, D. and Xue, Y.-B. (2013) Solar Energy and Residential Building Integration Technology and Application. International Journal of Clean Coal and Energy, 2, 8-12. http://dx.doi.org/10.4236/ijcce.2013.22B002

[3] European Council (2002) Energy Performance Building Directive of 16 December 2002 on the Energy Performance in Buildings.

[4] Ke, J. (2005) No.78 Guidelines on the Development of Energy-Saving and Ground-Saving Residential and Public Buildings in China.

[5] Editorial Board (2007) National Technical Measures for Design of Civil Construction-Special Edition of Energy Conservation. China Planning Press, Beijing. 